\title{
Peritonitis Caused by Internal Migration of the Percutaneous Transhepatic Biliary Drainage Catheter
}

\author{
So Hyun Ahn, Sung Ho Ki, Chang Yul Oh, Woo Hyun Cho, Jong Hun Lee, Yong Seok Lee, Hee Joo Lee \\ Department of Internal Medicine, Pohang St. Mary's Hospital, Pohang, Korea
}

Percutaneous transhepatic biliary drainage (PTBD) is a modality that is used to decompress obstructive jaundice due to impacted stones, benign stricture or cancer. The PTBD catheter is removed percutaneously after the restoration of internal biliary drainage. We experienced a case of a 62-year-old man with peritonitis due to the migration of the PTBD catheter into the peritoneal cavity; we successfully removed it using peroral endoscopy. Although rare, the PTBD catheter may migrate into the peritoneal cavity during the removal of it. In these cases, clinicians should consider the peroral endoscopic removal of the PTBD catheter.

Korean J Pancreatobiliary 2016;21(2):107-111

\author{
Received Sep. 12, 2015 \\ Revised Nov. 12, 2015 \\ Accepted Nov. 14, 2015
}

Corresponding author: Sung $\mathrm{Ho} \mathrm{Ki}$

Department of Internal Medicine, Pohang St. Mary's Hospital, 17 Daejamdong-gil, Nam-gu, Pohang 37661, Korea

Tel. +82-54-260-8238 Fax. +82-54-278-4517

E-mail; sehoki@hanmail.net

\section{INTRODUCTION}

Percutaneous transhepatic biliary drainage (PTBD) is a modality that is used to decompress obstructive jaundice due to impacted stones, benign stricture or cancer. ${ }^{1-5}$ It has been reported to produce intra- and post-procedural complications such as sepsis, cholangitis, bile leak, hemorrhage, pneumothorax and dislodgement of the catheter. ${ }^{6-8} \mathrm{Al}-$ though rare, the PTBD catheter may migrate into the peritoneal cavity during the removal of it.

We experienced a case of a 62-year-old man with perito- nitis due to the migration of the PTBD catheter into the peritoneal cavity during the removal of it. Here, we report our case with a review of literatures.

\section{CASE}

A 62-year-old man visited us with chief complaints of right upper-quadrant (RUQ) pain and febrile sense. On physical examination, the patient showed blood pressure $90 / 60 \mathrm{mmHg}$, pulse rate $120 / \mathrm{min}$, respiratory rate 22 breaths $/ \mathrm{min}$, and body temperature $39.1^{\circ} \mathrm{C}$. Moreover, the 
patient also had severe tenderness on the RUQ. On clinical laboratory tests, the patient had a white blood cell count of $4,900 / \mathrm{mm}^{3}$, hemoglobin $10.9 \mathrm{~g} / \mathrm{dL}$, platelet counts of $182,000 / \mathrm{mm}^{3}$, total bilirubin $9.96 \mathrm{mg} / \mathrm{dL}$, AST $144 \mathrm{IU} / \mathrm{L}$, ALT $184 \mathrm{IU} / \mathrm{L}$, alkaline phosphatase $671 \mathrm{IU} / \mathrm{L}$, amylase 797

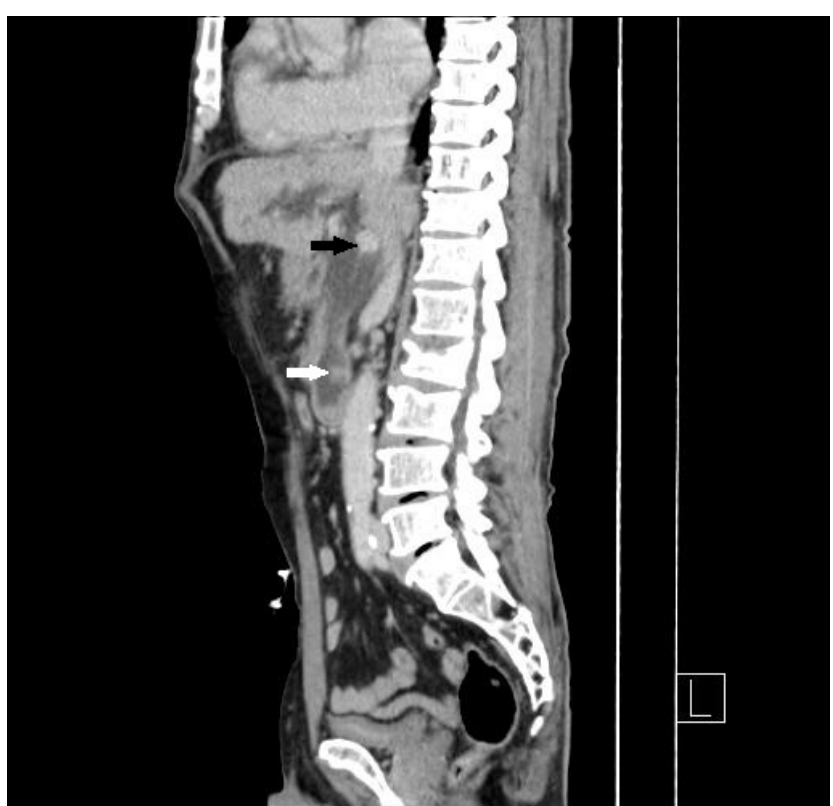

Fig. 1. Abdominal computed tomography (CT) scan showed biliary tree dilatation, gall bladder (GB) distension, and two common bile duct (CBD) stones (a $13 \times 10.5 \mathrm{~mm}$-black arrow, $11.3 \times 9.7 \mathrm{~mm}$-white arrow).

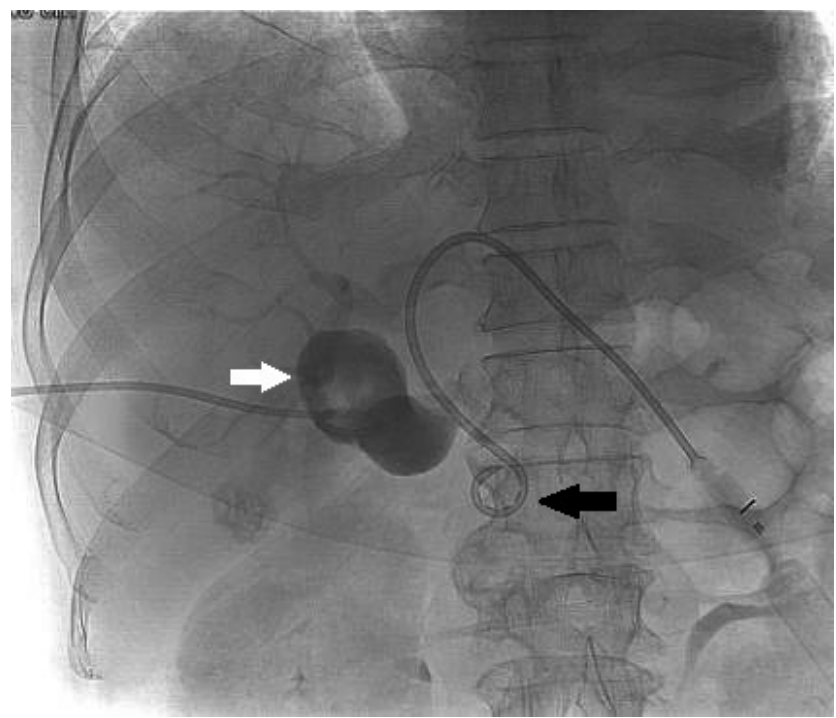

Fig. 2. Percutaneous transhepatic biliary drainage (PTBD) with placement of a $10.2 \mathrm{Fr}$ small pigtail drainage catheter via the left hepatic duct distal to the common bile duct (CBD) (black arrow). Percutaneous transhepatic gallbladder drainage with placement of an 8.5 Fr large pigtail drainage catheter (white arrow).
IU/L, lipase 2,497 IU/L, Erythrocyte sedimentation rate 45 $\mathrm{mm} / \mathrm{hr}$, and C-Reactive protein $17 \mathrm{mg} / \mathrm{dL}$. In addition, on blood coagulation test, the patient showed Prothrombin tme/activated partial thromboplastin time 11/31 seconds. On abdominal computed tomography (CT) scan, the patient had biliary tree dilatation and gallbladder distension due to two common bile duct (CBD) stones (Fig. 1).

On day 1, the patient had a decrease in blood pressure to 75/40 mmHg. The patient therefore, underwent emergency percutaneous transhepatic gallbladder drainage and PTBD rather than endoscopic retrograde cholangiopancreatography (ERCP) (Fig. 2). On day 9, CBD stones were removed by basket after ERCP (Fig. 3). On day 16, the patient underwent laparoscopic cholecystectomy. On day 19, the patient had migration of the PTBD catheter into the peritoneal cavity during the percutaneous removal of it at the bedside (Fig. 4). Then, the patient complained of abdominal pain. On abdominal CT scan, the patient had the tip of the PTBD catheter located in the abdominal cavity, which was accompanied by the detection of pneumoperitoneum (Fig. 5). The patient underwent emergent ERCP. After sweeping of the CBD by an extraction balloon, the PTBD pigtail catheter tip was pulled out into the duodenum through the ampulla.

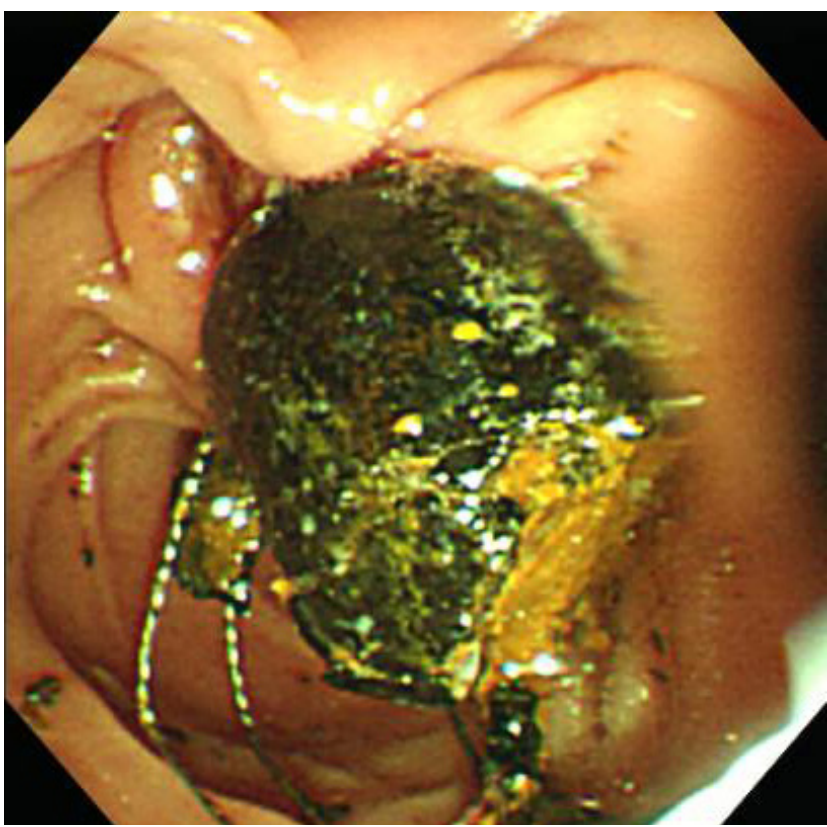

Fig. 3. Removal of common bile duct (CBD) stones by basket on endoscopy. 
The catheter tip was held by grasping forceps and retrieved with an endoscope (Fig. 6). On day 30, the patient was dis-

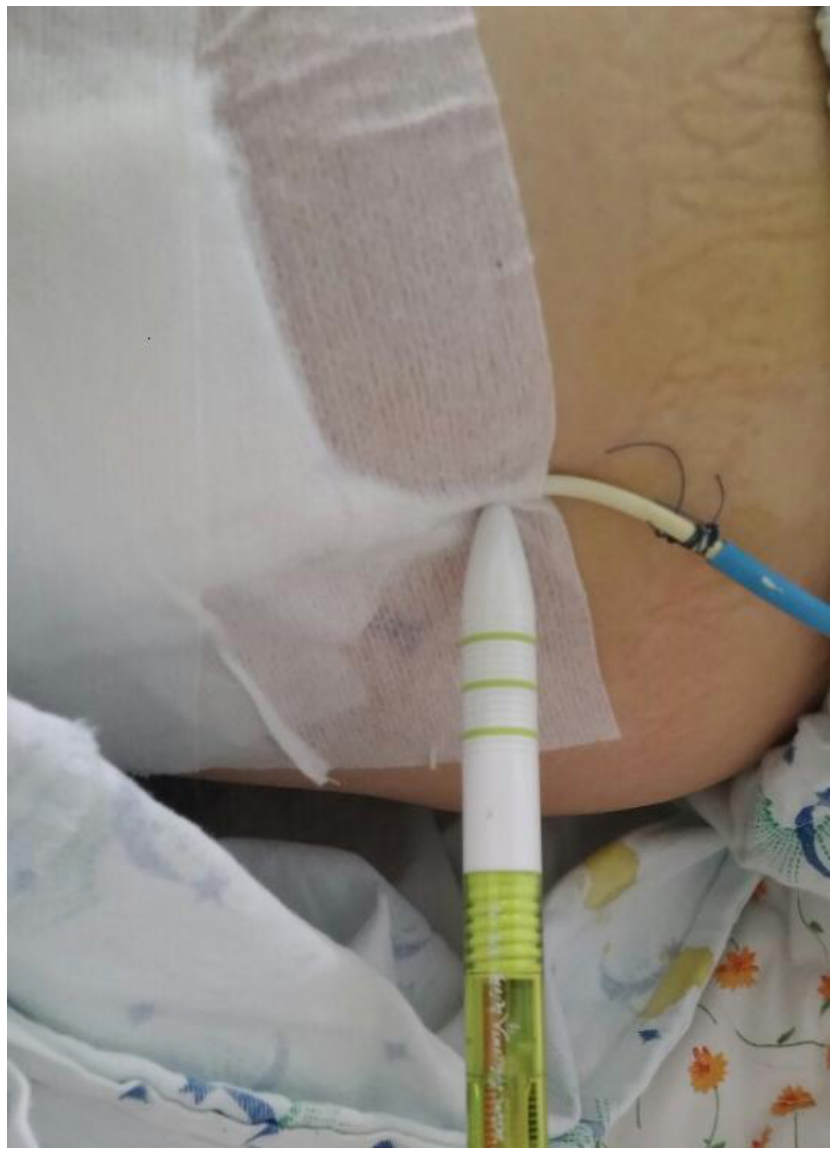

Fig. 4. This picture was sourced from another patient. The catheter was cut $3 \mathrm{~cm}$ from the skin. The pen indicates the cutting point of the percutaneous transhepatic biliary drainage (PTBD) catheter. charged without complications.

\section{Discussion}

Approximately 10-15\% of large stones are impacted in the bile duct and cannot be retrieved using conventional ERCP methods such as a balloon, basket, or mechanical basket lithotripsy. ${ }^{9}$ These cases pose challenging problems for clinicians; endoscopic managements, such as endoscopic papillary large balloon, ${ }^{10}$ direct cholangioscopy using an ultra-

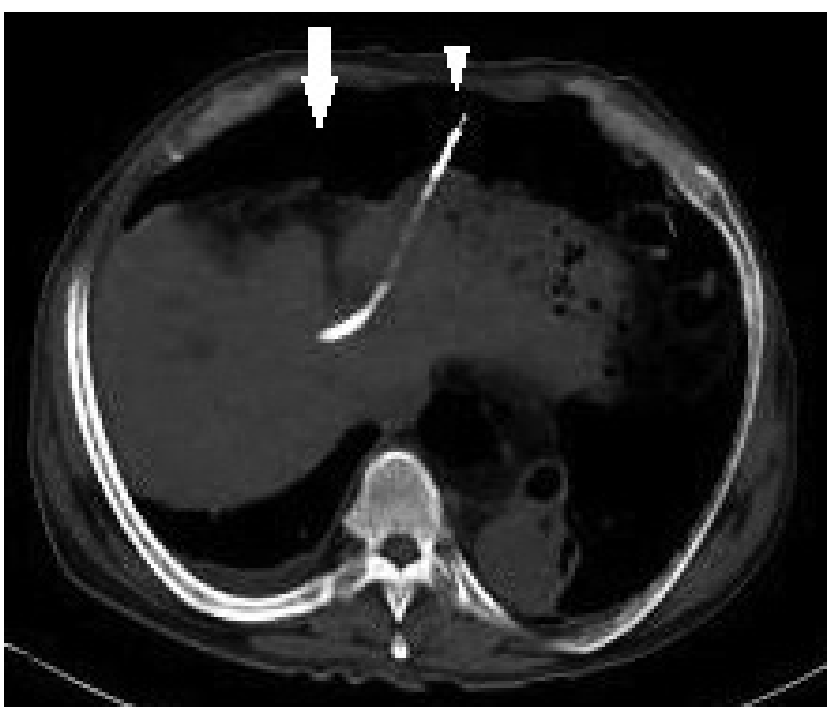

Fig. 5. On abdominal computed tomography (CT) scan, the percutaneous transhepatic biliary drainage (PTBD) catheter tip (arrow head) was located in the abdominal cavity, accompanied by the detection of pneumoperitoneum (white arrow).
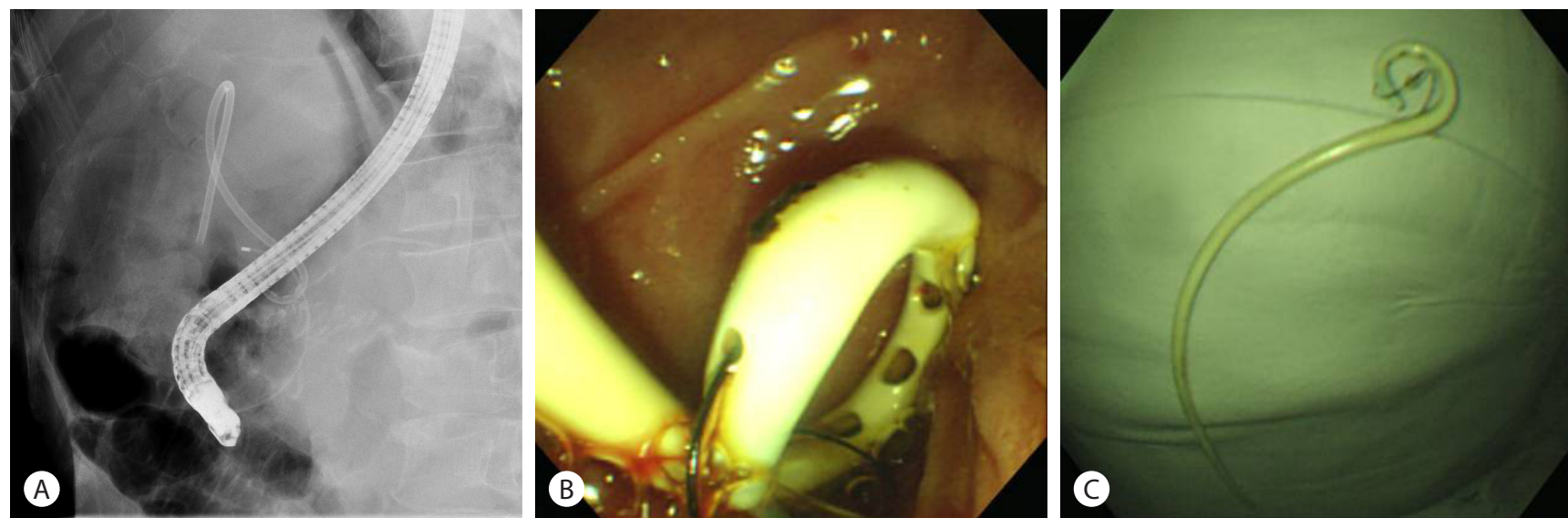

Fig. 6. (A) Endoscopic retrograde cholangio pancreatography (ERCP) showing removal of the percutaneous transhepatic biliary drainage (PTBD) catheter migrating into the peritoneal cavity. (B) Endoscopic findings of the PTBD pigtail catheter tip, which was pulled out into the duodenum through the ampulla after sweeping of the common bile duct (CBD) by an extraction balloon. (C) The catheter tip was retrieved with an endoscope after grasping the catheter with grasping forceps. 
slim ${ }^{11-13}$ and stenting with oral dissolution therapy in geriatric patients, ${ }^{14,15}$ have been attempted for the treatment of large CBD stones. ERCP has been recognized as the mainstay of therapy for the cholangitis secondary to biliary obstructions, such as CBD stones. However, the ERCP may be difficult or impossible in some clinical situations, including previous operation of the upper gastrointestinal (GI) tract, cardiopulmonary instability, patients' intolerance or phobia for endoscopy, and anomalies of the GI tract, which require alternative therapeutic modalities such as PTBD. ${ }^{3}$ The PTBD catheter has been reported to produce intra- or post-procedural complications. ${ }^{6-8}$ Of these, the most common intra-procedural complication is the infection, such as an abscess, cholangitis, peritonitis, cholecystitis, pancreatitis or sepsis. Moreover, it may also cause hemobilia such as hepatic venous bleeding, portal venous bleeding, hepatic arterial bleeding and tumor bleeding. Furthermore, it may also produce pleural complications such as pleural effusion, empyema, pneumothorax, hemothorax, and biliopleural fistula. On the other hand, post-procedural complications, such as bile leak, anastomotic strictures, and PTBD tube dislodgement of PTBD tube. ${ }^{9}$ One may assume that internal migration of the PTBD catheter is one of the procedural complications. To our knowledge, however, this has not been described in the literature. The PTBD catheter is removed percutaneously after the restoration of internal biliary drainage.

In the current case, the patient underwent ERCP for the removal of CBD stones, followed by a laparoscopic cholecystectomy. During the removal of the PTBD catheter, the cutting tube moves depending on the respiration. With the migration of the PTBD catheter into the peritoneal cavity, the patient had peritonitis. The PTBD tube could not be removed percutaneously because its outer tip was completely invisible. It was unavoidable, however, to remove the migrated PTBD catheter causing peritonitis. Therefore, we first considered the ERCP as a modality to remove it. Otherwise, we planned to perform surgical operations. After sweeping of the CBD by an extraction balloon, the PTBD pigtail catheter tip was pulled out into the duodenum through the am- pulla. The catheter tip was held by grasping forceps and retrieved with an endoscope.

Although rare, the PTBD catheter may migrate into the peritoneal cavity during the removal of it. In these cases, clinicians should consider the peroral endoscopic removal of the PTBD catheter. Its migration into the peritoneal cavity should be prevented during the removal of it. Therefore, the PTBD tube should be seized by grasping forceps and the length of the remaining part should be relatively greater in cutting the PTBD tube.

\section{요 약}

경피경간담즙배액술은 담석, 양성협착, 악성종양 등에 의 한 폐쇄성 황달을 감압시키기 위한 방사선학적 방법이다. 담 관을 통한 담즙의 내부배액이 회복되면 경피경간담즙배액 도관은 경피적으로 제거할 수 있다. 본례에서는 병상에서 경 피경간담즙배액 도관을 제거할 때, 도관이 복강으로 이동하 여 복막염이 발생하였고 경구내시경으로 도관을 제거하였 다. 경피경간담즙배액 도관을 제거할 때는 도관이 복강으로 이동하지 않도록 주의하여야 하며, 부주의로 인하여 도관이 복강으로 이동하였을 경우에는 경구내시경으로 도관을 제 거할 후 있다.

국문 색인: 도관, 담즙정체, 배액, 복막염, 내시경

\section{Conflicts of Interest}

The author has no conflicts to disclose.

\section{REFERENCES}

1. Nakayama T, Ikeda A, Okuda K. Percutaneous Transhepatic Drainage of the Biliary Tract: Technique and Results in 104 Cases. Gastroenterology 1978;74:554-559.

2. Ferrucci JT Jr, Mueller PR, Harbin WP. Percutaneous Transhepatic Biliary Drainage: Technique, Results, and Applications. Radiology 1980;135:1-13.

3. Park YS, Kim JH, Choi YW, Lee TH, Hwang CM, Cho YJ, Kim KW. Percutaneous Treatment of Extrahepatic Bile Duct Stones Assisted by Balloon Sphincteroplasty and Occlusion Balloon. Korean J Radiol 2005;6:235-240

4. Covey AM, Brown KT. Percutaneous Transhepatic Biliary Drainage. 
Tech Vasc Interv Radiol 2008;11:14-20.

5. Takada T, Yasuda H, Hanyn F. Technique and Management of Percutaneous Transhepatic Cholangial Drainage for Treating an Obstructive Jaundice. Hepatogastroenterology 1995;42:317-322.

6. Clouse ME, Evans D, Costello P, Alday M, Edwards SA, McDermott WV Jr. Percutaneous Transhepatic Biliary Drainage. Complications due to Multiple Duct Obstructions. Ann Surg 1983;198:25-29.

7. Muller PR, van Sonnenberg E, Ferrucci JT Jr. Percutaneous Biliary Drainage: Technical and Catheter-related Problems in 200 Procedures. AJR Am J Roentgenol 1982;138:17-23.

8. Saad WE, Wallace MJ, Wojak JC, Kundu S, Cardella JF. Quality Improvement Guidelines for Percutaneous Transhepatic Cholangiography, Biliary Drainage, and Percutaneous Cholecystostomy. J Vasc Interv Radiol 2010;21:789-795.

9. Lee DK, Jahng JH. Alternative Methods in the Endoscopic Management of Difficult Common Bile Duct Stones. Dig Endosc 2010;22:7984.

10. Jeong S, Ki SH, Lee DH, et al. Endoscopic Large-balloon Sphincteroplasty without Preceding Sphincterotomy for the Removal of
Large Bile Duct Stones: a Preliminary Study. Gastrointest Endosc 2009:70:915-922.

11. Moon JH, Ko BM, Choi HJ, et al. Intraductal Balloon-guided Direct Peroral Cholangioscopy with an Ultra-slim Upper Endoscope. Gastrointest Endosc 2009;70:297-302.

12. Moon JH, Ko BM, Choi HJ, et al. Direct Peroral Cholangioscopy Using an Ultra-slim Upper Endoscope for the Treatment of Retained Bile Duct Stones. Am J Gastroenterol 2009;104:2729-2733.

13. Choi HJ, Moon JH, Ko BM, et al. Overtube-balloon-assisted Direct Peroral Cholangioscopy by Using an Ultra-slim Upper Endoscope. Gastrointest Endosc 2009;69:935-940.

14. Li KW, Zhang XW, Ding J, Chen T, Wang J, Shi WJ. A Prospective Study of the Efficacy of Endoscopic Biliary Stenting on Common Bile Duct Stones. J Dig Dis 2009;10:328-331.

15. Han J, Moon JH, Koo HC, et al. Effect of Biliary Stenting Combined with Ursodeoxycholic Acid and Terpene Treatment on Retained Common Bile Duct Stones in Elderly Patients: A Multicenter Study. Am J Gastroenterol 2009;104:2418-2421. 